\title{
KADAR MALONDIALDEHID DAN AKTIVITAS ENZIM SUPEROKSIDA DISMUTASE PADA HIPERTENSI DAN NORMOTENSI
}

\author{
Resti Rahma Dianti ${ }^{1 *}$, Rusdi², Dian Evriyani ${ }^{2}$ \\ ${ }^{1}$ Prodi Biologi FMIPA Universitas Negeri Jakarta, Indonesia. ${ }^{2}$ Prodi Pendidikan Biologi FMIPA Universitas \\ Negeri Jakarta, Indonesia. \\ *Email address: resti.rahmadianti@yahoo.com
}

\begin{abstract}
Hypertension is a condition of high blood pressure caused by many factors. One of them is endothelial dysfunction indicated from malondialdehyde (MDA) level. The production of MDA is primarily prevented by endogenous antioxidant such as superoxide dismutase (SOD). This study aimed to identify the differences between level of MDA and the activity of SOD in hypertensive and normotensive. It also aimed to identify the correlation between MDA level and SOD activity in both group. This study was conducted in laboratory of animal physiology FMIPA UNJ on June to September 2015. This research used an Ex-Post facto method with a cross-sectional design. A total of 30 serum samples $(\mathrm{N} 1=\mathrm{N} 2=15)$ was examined to identify MDA level and SOD activity. Data of MDA level and SOD activity was analyzed by Mann-Whitney test and t-test, respectively. Correlation between MDA level and SOD activity was analyzed by Pearson Correlation test in normotensive group and by Spearman's Rho test in hypertensive group. Based on the results, mean value MDA level in normotensive was $0,465 \pm 0,118 \mathrm{nmol} /$ $\mathrm{mL}$ and in hypertensive is $1,279 \pm 0,307 \mathrm{nmol} / \mathrm{mL}$. MDA level in normotensive was significantly different than hypertensive (Sig. $=0,000$ ). Mean value SOD activity in normotensive was $2,307 \pm 0,739 \mathrm{u} / \mathrm{mL}$, and in hypertensive was $2,131 \pm 0,422 \mathrm{u} / \mathrm{mL}$. SOD activity was not significantly different in normotensive and hypertensive (Sig. $=0,432)$. In conclusion, there was no correlation between MDA level and SOD activity in hypertensive and normotensive group.
\end{abstract}

Keywords: hypertension, MDA, SOD

\section{PENDAHULUAN}

Hipertensi merupakan masalah kesehatan yang sangat mempengaruhi angka morbiditas maupun mortalitas baik di negara maju maupun berkembang (Chiang dan Chen, 2008). Pada tahun 2013 diketahui prevalensi hipertensi di Indonesia sebesar 26.5\% (Kementerian Kesehatan RI, 2014). Hipertensi adalah suatu kondisi ketika tekanan darah sistolik $\geq 140 \mathrm{mmHg}$ dan tekanan darah diastolik $\geq 90 \mathrm{mmHg}$. (Kaplan, 1992). Salah satu penyebab hipertensi adalah stres oksidatif. Stres oksidatif adalah keadaan dimana terjadi ketidakseimbangan antara pembentukan Reactive Oxygen Species (ROS) dan sistem pertahanan antioksidan yang berlangsung lama (Aquil, 2013; Juranek dan Bezek, 2005). Hasil dari reaksi antara radikal bebas dan fosfolipid membran sel epitelium salah satunya adalah malondialdehid (MDA). Pembentukan MDA dapat dicegah oleh senyawa antioksidan yang berasal dari dalam tubuh, seperti superoksida dismutase (SOD), katalase (CAT), dan glutathione peroxidase (GPx). Namun, yang menjadi pertahanan tubuh pertama dalam mengatasi stres oksidatif adalah SOD (Rajkumar et al., 2008). Sehingga keberadaan SOD sangat penting di dalam tubuh untuk menangkal radikal bebas. 


\section{METODE PENELITIAN}

Metode penelitian ini adalah Ex Post Facto dengan desain cross-sectional. Pengambilan sampel dilakukan dengan purposive sampling yang memenuhi kriteria inklusi. Penelitian ini dilakukan Laboratorium Fisiologi, Laboratorium Mikrobiologi dan Genetika, dan Laboratorium Kultur Jaringan FMIPA UNJ pada bulan Januari sampai September 2015. Pengukuran kadar MDA dilakukan dengan metode TBARS dengan spektrofotometri pada panjang gelombang $530 \mathrm{~nm}$. Untuk pengukuran aktivitas enzim SOD dengan menggunakan kit Ransod; Randox Labs. Cat. No. SD 125, Crumlin, UK.

Analisis Data, Untuk analisis perbedaan kadar MDA menggunakan uji Mann Whitney. Untuk analisis perbedaan aktivitas enzim SOD menggunakan uji t-test independent. Korelasi antara kadar MDA dengan aktivitas SOD dengan menggunakan uji corelation bivariate Pearson untuk kelompok normotensi, dan uji corelation bivariate Spearman untuk kelompok hipertensi.

\section{HASIL DAN PEMBAHASAN}

Hasil pengukuran kadar MDA rata-rata pada normotensi adalah sebesar 0,465 $\pm 0,118 \mathrm{nmol} / \mathrm{mL}$, sedangkan pada penderita hipertensi yaitu sebesar $1,279 \pm 0,307 \mathrm{nmol} / \mathrm{mL}$ (Tabel 1.). Berdasarkan uji beda didapat nilai signifikansi sebesar 0,000, hal ini berarti terdapat perbedaan kadar MDA antara kelompok normotensi dan hipertensi. Kadar MDA rata-rata pada kelompok hipertensi lebih tinggi dibandingkan dengan kelompok normotensi. Hal ini disebabkan karena kondisi stres oksidatif yang dapat menyebabkan disfungsi endotelium pada hipertensi. Ketersediaan NO sebagai vasodilator alami di dalam tubuh terganggu oleh ROS yang banyak diproduksi di dalam tubuh. Hal ini didukung oleh pernyataan Gornik dan Creager (2004) dan Bevers et al. (2006) yang menyatakan bahwa kenaikan peroksidasi lipid pada hipertensi berkaitan dengan ROS yang menggangu ketersediaan NO. Kadar MDA yang lebih tinggi pada kelompok hipertensi disebabkan karena ROS yang meningkat. ROS di dalam tubuh dapat meningkatkan aktivitas Angiotensin Converting Enzym (ACE) yang berfungsi untuk membentuk Angiotensin II. Selain sebagai vasokontriktor, Angiotensin II juga dapat meningkatkan produksi ROS dalam tubuh dengan cara meningkatkan aktivitas NADPH oksidase dalam menghasilkan ion superoksida, seperti yang dikatakan oleh Meera dan Marcus (2012).

Tabel 1. Hasil Pengukuran Kadar MDA dan Aktivitas Enzim SOD

\begin{tabular}{lll}
\hline & Kadar MDA $(\mathrm{nmol} / \mathrm{mL})$ & Aktivitas SOD $(\mathrm{u} / \mathrm{mL})$ \\
\hline Normotensi $(\mathrm{n}=15)$ & $0,465 \pm 0,118$ & $2,307 \pm 0,739$ \\
Hipertensi $(\mathrm{n}=15)$ & $1,279 \pm 0,307 *$ & $2,131 \pm 0,422$ \\
\hline *: Sig. dengan normotensi & &
\end{tabular}

Hasil pengukuran aktivitas enzim SOD rata-rata pada kelompok normotensi adalah sebesar 2,307 $\pm 0,739 \mathrm{u} /$ $\mathrm{mL}$. Sedangkan nilai aktivitas enzim SOD rata-rata pada kelompok hipertensi adalah sebesar 2,131 $\pm 0,422 \mathrm{u} / \mathrm{mL}$ (Tabel 1.). Berdasarkan uji beda antara dua kelompok didapat nilai signifikansi sebesar 0,432, hal ini berarti tidak terdapat aktivitas enim SOD antara kelompok normotensi dan hipertensi. Aktivitas enzim SOD pada kelompok hipertensi lebih rendah daripada kelompok normotensi. Hal ini diduga karena ROS dapat merusak protein di dalam sel. Saat enzim SOD telah rusak atau terinaktivasi oleh ROS, maka aktivitas enzim SOD juga akan menurun. Hal ini didukung oleh pernyataan Aquil et al. (2013) dan Emmanuel (2002) yang menyatakan bahwa radikal bebas dapat 
menginaktivasi protein. Rendahnya aktivtas enzim SOD pada penderita hipertensi juga dapat disebabkan karena berkurangnya asupan tubuh terhadap antioksidan eksogen seperti vitamin E dan vitamin C. Antioksidan enzimatis dan nonenzimatis (vitamin antioksidan) bekerja sinergis dalam melindungi sel terhadap stres oksidatif., seperti yang dikatakan oleh Nourmohammadi et al. (2001).

Table 2. Nilai Sig. korelasi kadar MDA dan Aktivitas Enzim SOD

\begin{tabular}{lll}
\hline Kelompok & Koef. Korelasi & Sig. (2-tailed) \\
\hline Normotensi &, 438 &, $103^{*}$ \\
Hipertensi &,- 068 &, $809^{*}$ \\
\hline Ket: ${ }^{*}:<0,05$, tidak terdapat hubungan &
\end{tabular}

Tidak adanya perbedaan yang signifikan antara aktivitas enzim SOD pada kelompokhipertensi dan normotensi, diduga karena enzim SOD pada kedua kelompok masih berfungsi dengan baik. Hal ini disebabkan karena adanya adaptasi alami sel dalam tubuh terhadap kondisi stres oksidatif. Pada kondisi buruk, sel tubuh dapat membentuk pertahanan alami untuk mencegah kerusakan. Hal ini didukung oleh pernyataan Chandrasena et al., (2006) yang mengatakan bahwa di dalam tubuh terdapat respon peningkatan antioksidan pada kondisi stres oksidatif.

Berdasarkan hasil uji statistik corelation bivariate, tidak didapatkan hubungan antara kadar MDA dengan aktivitas enzim SOD pada kelompok normotensi maupun hipertensi. Hasil uji korelasi kadar MDA dengan aktivitas enzim SOD pada kelompok normotensi dan hipertensi dapat dilihat pada Tabel 2. Tidak terdapatnya hubungan antara kadar MDA dengan aktivitas enzim SOD dalam penelitian ini diduga karena MDA tidak hanya dihasilkan oleh ion superoksida saja, tetapi bisa juga disebabkan oleh oksidan reaktif lainnya yang termasuk ke dalam golongan peroksida. Substrat dari enzim SOD adalah superoksida, sedangkan produknya adalah hydrogen peroksida (H2O2) yang tidak dapat dinetralisir oleh SOD. Hal ini didukung oleh postulat Dahle et al. (1962) yang mengatakan bahwa hanya senyawa-senyawa peroksida yang mampu membentuk MDA.

\section{KESIMPULAN}

Kesimpulan pada penelitian ini antara lain, terdapat perbedaan kadar MDA antara kelompok normotensi dan hipertensi. Tidak terdapatnya perbedaan aktivitas enzim SOD antara kelompok normotensi dan hipertensi. Dan tidak terdapatnya hubungan antara kadar MDA dengan aktivitas enzim SOD pada kelompok normotensi maupun hipertensi.

\section{DAFTAR PUSTAKA}

Aquil Ahmad, Usha Singhal, Mohd Mobark Hossain, Najmul Islam, Imran Rizvi. 2013. The Role of the Endogenous Antioxidant Enzymes and Malondialdeyde in Essential Hypertension. Journal of Clinical and Diagnostic Research, 7(6): 987-990

Bevers, L. M., Braam, B., Post, J.A., Van Zonneveld, A. J., Rabelink, T. J., Koomans, H. A., Et Al. 2006. Tetrahydrobioprotein, But Not L-Arginine, Decrease NO Synthase Uncoupling In Cells Expressing High Levels Of Endothelial NO Synthase. Hypertension, 47 : 87-94

Chandrasena L.G., Chackrewarthy S., Perera T.M., dan Silva D. 2006. Erythrocyte Antioxidant Enzyme in Patient 
with Cataract. Annal of Clinical and Laboratory Science, 36 (2): 201-204

Chiang CE, Chen CH. 2008. Hypertension In The Asia Pacific Region. Journal of Human Hypertension, 22 : 441443

Dahle, L. K.; Hill, E. G.; Holman, R. T. 1962. The Thiobarbituric Acid Reaction and The Autoxidations of Polyunsaturated Fatty Acid Methyl Esters. Archives Biochemistry and Biophysics. 98, 253

Emmanuel C Opara. 2002. Oxidative stress, micronutrients, diabetesmellitus and its complications. The Journal of The Royal Society for The Promotion of Health, 122(1), 28-34

Gornik, H. L., and Creager, M. A. 2004. Arginine and Endothelial and Vascular Healthy. Journal of Nutrition. 134, 2880S-2887S

Juranek I, Bezek S. 2005. Controversy of Free Radical Hypotehsis: Reactive Oxygen Species-Cause or Consequence of Tissue Injury?. General Physiology and Biophysics, 24 : 263-78

Kaplan, N. M. 2014. Systemic Hypertension: Mechanism And Diagnosis, In Heart Disease. Philadelphia: Braunwald, E., W. B Saunders

Meera K. S., Sara Rani Marcus. 2012. Endothelial Dysfunction And Oxidative Stress In Hypertension. Asian Journal Of Medical Research, 1(3) : 84-89

Nourmohammadi I., Gohari L., Moddares M., dan Ghayoumi-Javinani A. 2001. Evaluation of Erythrocyte Glutation Peroxidase, Superoksida Dismutase and Total Antioxidants in Cataract Patiens. Archives of Iran Medicine, 4(3): 123-126

Rajkumar S., Praveen M.R., Gajjar D., Vasawada A.R., Alapure B., Patel D., dan Kapur S. 2008. Activity of Superoksida Dismutase Isoenzymes In Epithelial Cells Derived Fromdifferent Types of Age-Related Cataract. Jornal of Cataract Refractive Surgery, 34: 470-474 